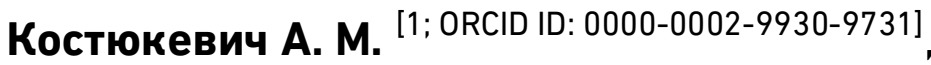
к.е.н., доцент

${ }^{1}$ Національний університет водного господарства та природокористування, м. Рівне

\title{
ПРОБЛЕМИ СТИМУЛЮВАННЯ РОЗВИТКУ МАЛОГО І СЕРЕДНЬОГО ПІДПРИЕМНИЦТВА НА РЕГІОНАЛЬНОМУ РІВНІ
}

Однією з проблем повільного розвитку малого і середнього бізнесу в транзитивних економіках $є$ недостатня узгодженість програм розвитку підприємництва, що реалізуються місцевими органами влади, та справжніх потреб суб'єктів підприємництва. Такий результат підтверджено на основі опитування представників малого і середнього бізнесу на прикладі однієї з локальних громад України. Доведено, що низька ефективність програм розвитку підприємництва зумовлена методологічною вадою, що зберігається у формуванні стратегій розвитку громад різного рівня.

Ключові слова: мале та середнє підприємництво; стимулювання розвитку підприємництва; територіальні громади; програми розвитку малого та середнього підприємництва.

Стимулювання розвитку малого і середнього підприємництва на регіональному і місцевому рівні відбувається, головним чином, за допомогою механізму програмно-цільового управління, який лежить в основі усієї моделі державного менеджменту. Такий підхід закріплений в Конституції України, а суть програмно-цільового методу і його застосування на різних рівнях бюджетного процесу визначена Бюджетним кодексом. При цьому в Україні передбачена реалізація державних програм економічного та соціального розвитку на основі прогнозів у відповідній сфері та їх використання у плануванні проєктів різного рівня державного сфери впливу.

Аналіз останніх досліджень. Про необхідність стимулювання малого та середнього підприємництва на регіональному рівні написано багато наукових праць і практичних посібників. Достатньо значні наукові доробки у цій сфері належать Н. І. Галан, 3. Варналій, В. Дергачовій, О. Кужель, О. Новицькій, В. Торопкову $[1 ; 2 ; 3 ; 4]$ та ін. Окремі аспекти цієї проблеми розглядаються на рівні органів державної влади, які формують програми розвитку підприємництва в 
Україні. Однак, незважаючи на вагомість зазначених напрацювань, не достатньо вирішеними залишаються проблеми стимулювання малого та середнього підприємництва на регіональному рівні.

Постановка завдання. У сфері розвитку підприємництва на різних рівнях державного управління та місцевого самоврядування затверджуються дво-трирічні програми, проте, як показує багаторічна практика, ефективність таких програм $€$ дуже низькою, оскільки їх реалізація, у більшості випадків не призводить до системних змін в підприємницькій активності.

Виклад основного матеріалу. Як видно 3 рис. 1, обсяги реалізованої продукції малими підприємствами в Україні зросли за вісім років лише на 20\%, попри наявність державних, регіональних і місцевих програм розвитку малого підприємництва. Такий ріст не відповідає потребам національної економіки, яка за значенням ВВП на душу населення $€$ після Молдови найбіднішою країною Європи.

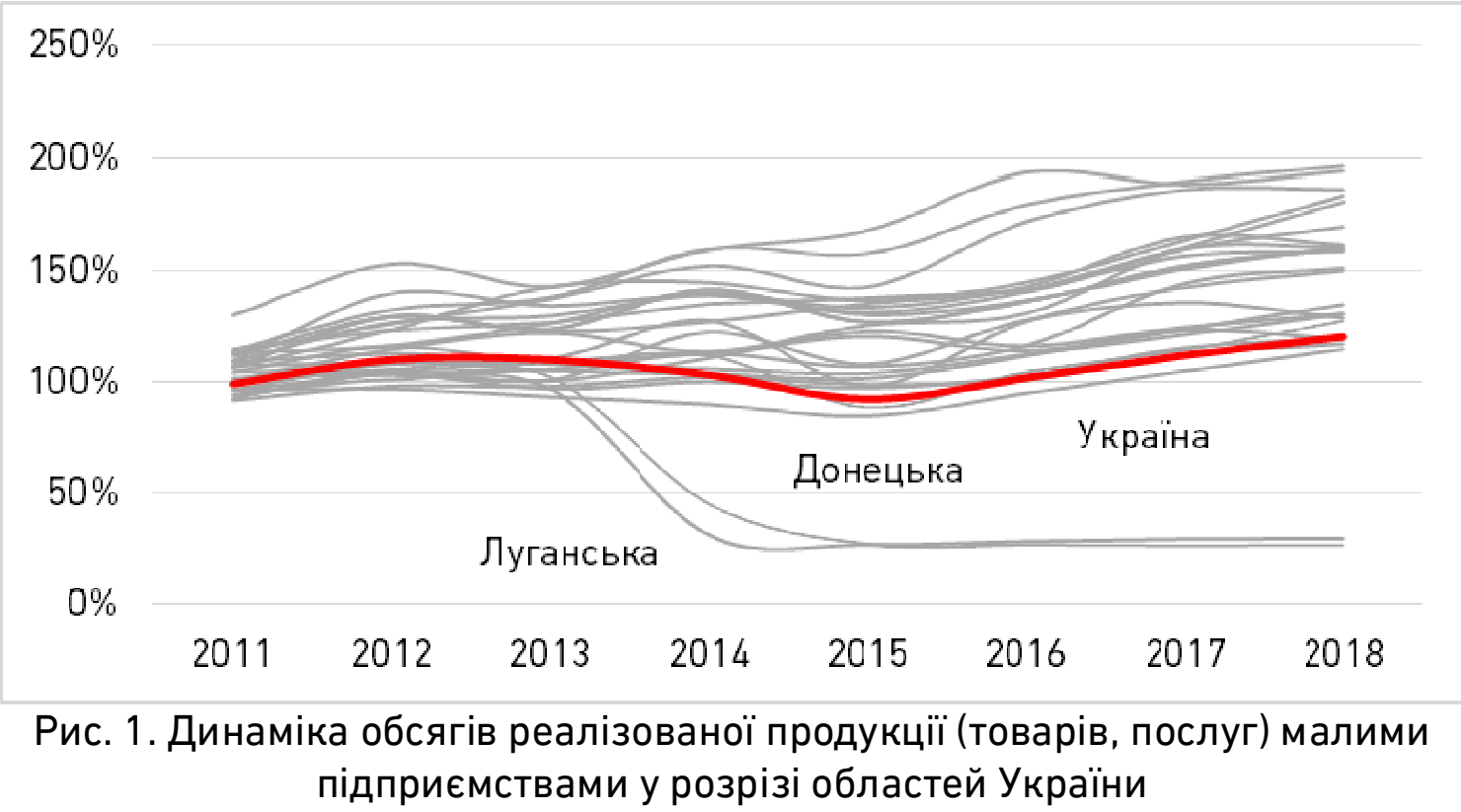

На таку ситуацію суттєво вплинула війна на Сході України, що розпочалася у 2014 році та анексія Криму, оскільки обсяги виробництва продукції малими підприємствами скоротилися більше ніж на 70\%. Серед усіх областей України вирізняються три (Кіровоградська, Вінницька і Тернопільська), в яких темпи росту обсягів реалізації продукції суб'єктами малого підприємництва суттєво випереджують інші області. Проте, цей ріст суттєво не вплинув на загальну динаміку розвитку підприємництва в країні, оскільки ці області разом займають лише 5,9\% сумарного обсягу реалізації продукції (табл. 1). А Тернопільська область залишається одним із аутсайдерів за показником обсягу реалізованої продукції малими підприємствами на 1000 осіб, що проживають на цій 
території. Більш вагомим фактором, що уповільнив загальний ріст малого підприємництва в країні, стала повільна динаміка виробленої продукції в м. Київ, Дніпропетровській області, Харківській області, які в сукупності створюють $49 \%$ усієї реалізованої продукції.

Таблиця 1

Обсяги реалізованої продукції малими підприємствами у розрізі областей України

\begin{tabular}{|c|c|c|c|c|}
\hline \multirow[b]{2}{*}{$\begin{array}{c}\text { Адміністративна } \\
\text { одиниця }\end{array}$} & \multirow{2}{*}{$\begin{array}{c}\text { Обсяг } \\
\text { реалізованої } \\
\text { продукції у } \\
2020 \text { році, } \\
\text { млрд грн }\end{array}$} & \multicolumn{2}{|c|}{$\begin{array}{c}\text { Частка адміністративної } \\
\text { одиниці в структурі вартості } \\
\text { реалізованої продукції }\end{array}$} & \multirow{2}{*}{$\begin{array}{c}\text { Обсяг } \\
\text { реалізованої } \\
\text { продукції на } \\
1000 \text { осіб } \\
\text { населення, } \\
\text { грн/1000 осіб }\end{array}$} \\
\hline & & $\begin{array}{c}\text { у \% до } \\
\text { сумарного } \\
\text { показника в } \\
\text { Україні }\end{array}$ & $\begin{array}{c}\text { у тому числі з } \\
\text { наростаючим } \\
\text { підсумком }\end{array}$ & \\
\hline М. Київ & 603,04 & $33,61 \%$ & $33,61 \%$ & 204,5 \\
\hline Дніпропетровська & 160,72 & $8,96 \%$ & $42,57 \%$ & 50,1 \\
\hline Харківська & 118,56 & $6,61 \%$ & $49,18 \%$ & 44,3 \\
\hline Одеська & 111,21 & $6,20 \%$ & $55,38 \%$ & 46,7 \\
\hline Київська & 109,11 & $6,08 \%$ & $61,46 \%$ & 61,7 \\
\hline Львівська & 89,81 & $5,01 \%$ & $66,47 \%$ & 35,6 \\
\hline Запорізька & 58,48 & $3,26 \%$ & $69,73 \%$ & 34,3 \\
\hline Полтавська & 50,53 & $2,82 \%$ & $72,55 \%$ & 36,0 \\
\hline Вінницька & 47,70 & $2,66 \%$ & $75,20 \%$ & 30,5 \\
\hline Миколаївська & 41,19 & $2,30 \%$ & $77,50 \%$ & 36,4 \\
\hline Черкаська & 39,59 & $2,21 \%$ & $79,71 \%$ & 32,8 \\
\hline Чернівецька & 11,77 & $2,21 \%$ & $81,91 \%$ & 13,0 \\
\hline Кіровоградська & 37,31 & $2,08 \%$ & $83,99 \%$ & 39,4 \\
\hline Донецька & 33,21 & $1,85 \%$ & $85,84 \%$ & 8,0 \\
\hline Херсонська & 28,97 & $1,61 \%$ & $87,46 \%$ & 27,9 \\
\hline Хмельницька & 28,06 & $1,56 \%$ & $89,02 \%$ & 22,2 \\
\hline Житомирська & 27,25 & $1,52 \%$ & $90,54 \%$ & 22,3 \\
\hline Чернігівська & 25,87 & $1,44 \%$ & $91,98 \%$ & 25,7 \\
\hline Волинська & 25,66 & $1,43 \%$ & $93,41 \%$ & 24,8 \\
\hline Сумська & 23,70 & $1,32 \%$ & $94,74 \%$ & 21,9 \\
\hline Івано-Франківська & 23,29 & $1,30 \%$ & $96,03 \%$ & 17,0 \\
\hline Тернопільська & 21,20 & $1,18 \%$ & $97,22 \%$ & 20,3 \\
\hline Рівненська & 20,26 & $1,13 \%$ & $98,35 \%$ & 17,5 \\
\hline Закарпатська & 17,45 & $0,97 \%$ & $99,32 \%$ & 13,9 \\
\hline Луганська & 12,23 & $0,68 \%$ & $100,00 \%$ & 5,7 \\
\hline Всього & 1766,15 & $100,00 \%$ & & \\
\hline
\end{tabular}

Джерело: розроблено авторами на основі [5].

У 2016 році Україна і ЄС уклали Deep and Comprehensive Free Trade Area (DCFTA). Але вона також не стала дієвим стимулом для динамічного розвитку малого підприємництва. В окремих областях у 2020 році відбулося навіть зменшення обсягів реалізованої продукції 
(Івано-Франківська область (-5\%), Херсонська область (-3\%), Рівненська область (-2\%).

Однією 3 головних причин повільного розвитку малого підприємництва $€$ недостатня узгодженість програм розвитку підприємництва, що реалізуються місцевими органами влади, та справжніх потреб суб'єктів підприємництва.

У результаті опитування представників малого і середнього бізнесу (150 респондентів) в м. Рівне, виявлено, що пріоритетним напрямом фінансової підтримки бізнесу підприємці вважають здешевлення кредитів (23\% усіх пропозицій) (рис. 2).

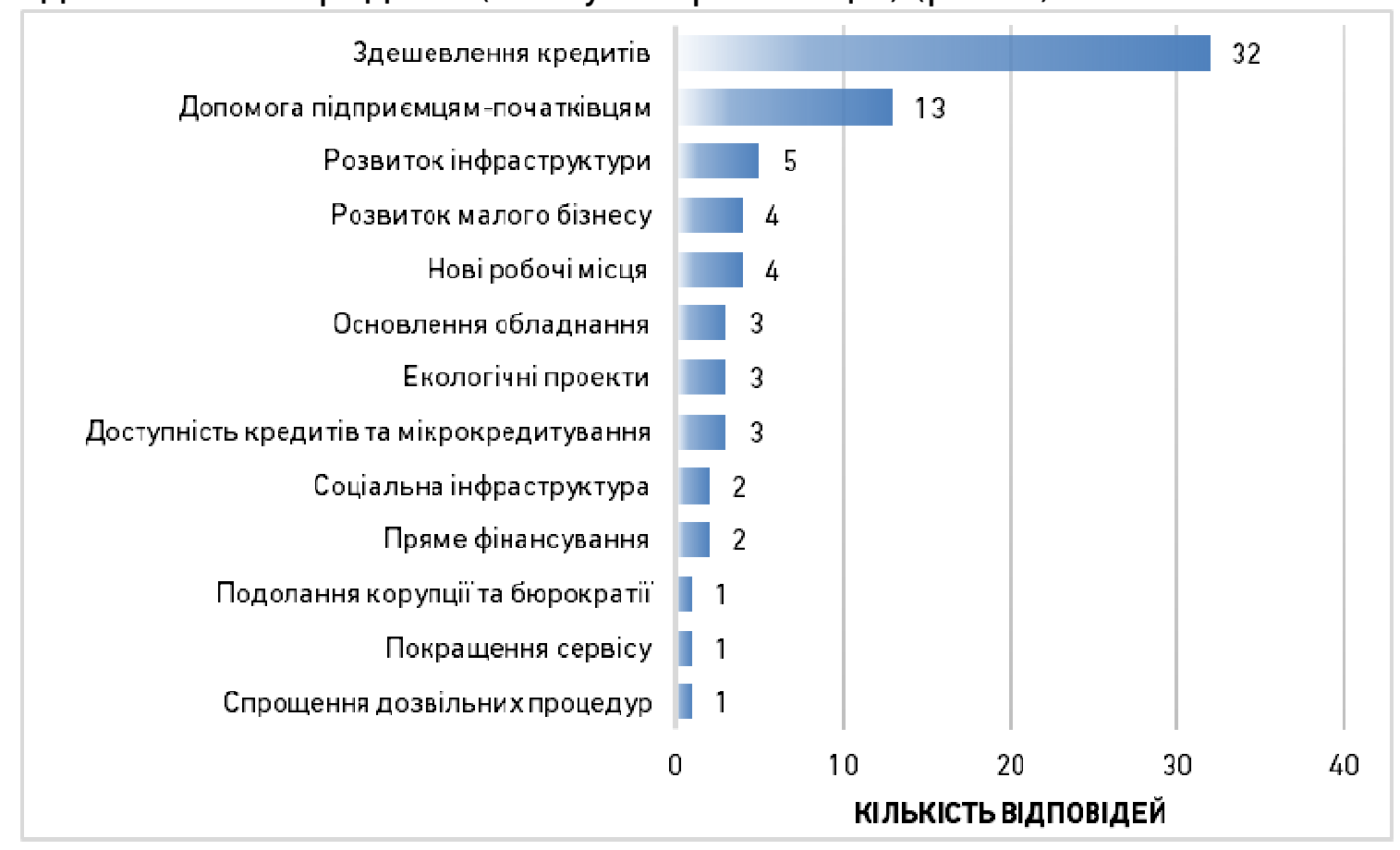

Рис. 2. Пріоритетні напрями фінансової підтримки бізнесу

Проте, такий інструмент не став ключовим у «Програмі розвитку малого і середнього підприємництва в м. Рівне на 2020-2021 роки» [6], а тому у 2019 році часткову компенсацію відсоткових ставок за користування кредитами банків отримали лише 2 підприємці на суму 126,6 тис. грн, а у 2018 році, як зазначено у звіті про виконання цієї програми за 2018 рік, «інвестиційні проєкти на розгляд не надходили, компенсація не здійснювалася». Подібні невідповідності можна спостерігати у сфері розвитку підприємницької інфраструктури та інформаційної підтримки. А тому проєкти і заходи, за допомогою реалізації яких повинні досягатися загальні цілі розвитку місцевого бізнесу не мають суттєвого впливу на процеси розвитку бізнесу.

Іншою проблемою $€$ те, що більшість програм підтримки підприємництва не синхронізовані 3 очікуваними результатами 
стратегій розвитку регіонів і територіальних громад. Не дотримується головний принцип «принцип цілісності, який забезпечується розробленням взаємоузгоджених прогнозних i програмних документів економічного і соціального розвитку України, окремих галузей економіки та окремих адміністративнотериторіальних одиниць на коротко- та середньостроковий періоди і на більш тривалий період», який закладений в Законі України «Про державне прогнозування та розроблення програм економічного i соціального розвитку України» [7].

Для реалізації цього принципу регіональні органи влади і місцевого самоврядування наділені належними повноваженнями у сфері розвитку малого і середнього підприємництва, серед яких:

1) визначення регіональних та місцевих пріоритетів і видів державної підтримки з урахуванням загальнодержавних пріоритетів;

2) розроблення проєктів регіональних та місцевих програм розвитку малого і середнього підприємництва, забезпечення їх виконання 3 урахуванням загальнодержавних пріоритетів, національних і регіональних соціально-економічних, екологічних, культурних та інших особливостей, здійснення моніторингу виконання таких програм.

Реалізація цих повноважень потребує методичного супроводу щодо встановлення пріоритетів проєктів у портфелях проєктів на основі цілей і завдань стратегічних документів вищих рівнів. Проте на сьогодні такий інструментарій відсутній, а тому ще на етапі розроблення програм закладаються неузгоджені між собою i недосяжні планові результати та індикатори.

Наведені проблеми застосування програмно-цільового управління у механізмах стимулювання малого підприємництва посилюються недостанім зв'язком із стратегіями розвитку територій. Адже програми різних рівнів якраз і $\epsilon$ інструментом досягнення стратегічних та операційних цілей стратегій. У разі відсутності такого зв'язку зникає цінність як стратегічного планування, результати якого стають декларативними, так і системи програмно-цільового управління, яка споживає ресурси, що націлені, насамперед на отримання продуктів проєктів і програм, сукупність яких не створює належних результатів, без яких неможливо змінити стан системи, заради чого розробляють стратегії та програми.

В Україні ця проблема стоїть дуже гостро. Адже з одного боку регіональна влада та органи місцевого самоврядування змушені розробляти стратегії розвитку, щоб мати можливість брати участь у конкурсах Державного фонду регіонального розвитку, який $\epsilon$ 
основним донором інвестиційний ресурсів для розвитку громад, а 3 іншого - запит на якісне науково обґрунтоване стратегування i програмування на регіональному і місцевому рівні $\epsilon$ низьким, оскільки воно не інтегроване у реальну систему прийняття стратегічних рішень та розподілу ресурсів. Як наслідок, в Україні немає практики оцінювання ефективності роботи органів регіональної влади та місцевого самоврядування за результатами досягнення цілей затверджених ними стратегій. Внаслідок недовіри до самого інституту стратегування про затверджені стратегії, переважно, забувають відразу після їх прийняття, а рівень досягнення стратегічних цілей й індикаторів ніколи не є предметом публічних дискусій під час виборчих кампаній національного, регіонального та місцевого рівнів.

Орієнтація на індикатори процесу (наприклад, показник кількість суб'єктів підприємництва на 10 тис. населення, який часто $€$ цільовим у регіональних і місцевих стратегіях) не повинен бути кінцевою ціллю стратегій і програм, оскільки він створює лише передумови для якісних змін у бізнесі. Підтвердження цієї тези можна знайти, порівнюючи структури різних показників, що характеризують розвиток підприємництва в Україні і ЄС (див. табл. 2).

Таблиця 2

Порівняльна характеристика структур показників розвитку малого і середнього бізнесу

\begin{tabular}{|c|c|c|c|c|}
\hline $\begin{array}{c}\text { Види суб'єктів } \\
\text { підприємництва }\end{array}$ & Об'єкти порівняння & $\begin{array}{c}\text { Кількість } \\
\text { суб'єктів } \\
\text { господарювання, } \\
\%\end{array}$ & $\begin{array}{c}\text { Кількість } \\
\text { зайнятих } \\
\text { працівників, } \\
\%\end{array}$ & $\begin{array}{c}\text { Додана } \\
\text { вартість за } \\
\text { витратами } \\
\text { виробництва, } \\
\% \\
\end{array}$ \\
\hline \multirow{3}{*}{$\begin{array}{l}\text { Суб'єкти мікро- } \\
\text { підприємництва }\end{array}$} & $E C$ & 92,7 & 29,2 & 21,1 \\
\hline & Україна & 96,8 & 35,2 & 8,9 \\
\hline & Індекс (Україна/ЄС) & 1,04 & 1,21 & 0,42 \\
\hline \multirow{3}{*}{$\begin{array}{l}\text { Суб'єкти малого } \\
\text { підприємництва } \\
\text { (без урахування } \\
\text { суб'єктів мікро- } \\
\text { підприємництва) } \\
\end{array}$} & $E C$ & 6,1 & 20,4 & 18,2 \\
\hline & Україна & 2,4 & 11,7 & 10,7 \\
\hline & Індекс (Україна/ЄС) & 0,40 & 0,58 & 0,59 \\
\hline \multirow{3}{*}{$\begin{array}{l}\text { Суб'єкти } \\
\text { середнього } \\
\text { підприємництва }\end{array}$} & $E C$ & 1,0 & 17,3 & 18,5 \\
\hline & Україна & 0,8 & 32,2 & 39,4 \\
\hline & Індекс (Україна/ЄС) & 0,79 & 1,86 & 2,13 \\
\hline \multirow{3}{*}{$\begin{array}{l}\text { Суб'єкти } \\
\text { великого } \\
\text { підприємництва }\end{array}$} & $E C$ & 0,20 & 33,1 & 42,2 \\
\hline & Україна & 0,02 & 20,9 & 41,0 \\
\hline & Індекс (Україна/ЄС) & 0,10 & 0,63 & 0,97 \\
\hline
\end{tabular}

Джерело: розроблено авторами на основі [5]. 
Як видно з табл. 2, в структурі суб'єктів підприємництва за розмірами бізнесу частка суб'єктів мікропідприємництва в Україні більша на $4 \%$ ніж в країнах ЄС, а за структурою зайнятості - на $21 \%$. Проте за доданою вартістю за витратами виробництва частка суб'єктів мікропідприємництва складає в Україні лише 8,9\%, тоді я к країнах ЄС цей показник становить 21,1\%. Саме цей показник свідчить про вагомість мікропідприємництва в структурі економіки. Щоправда орієнтиром для цільових значень показників потрібно брати внутрішні потреби, оскільки Україна ще не імплементувала Регламент ЄC 70/2011, у якому значення критеріїв, за якими проводиться розподіл суб'єктів підприємництва на групи, відмінні від встановлених українським законодавством.

Висновки. Узагальнюючи результати дослідження, можна стверджувати, що проблемою повільного розвитку малого i середнього підприємництва в транзитивних економіках є недостатня узгодженість програм розвитку підприємництва, що реалізуються місцевими органами влади, та справжніх потреб суб'єктів підприємництва. Низька ефективність програм розвитку підприємництва зумовлена методологічною вадою, що зберігається у формуванні стратегій розвитку громад різного рівня.

1. Варналій 3. С. Конкуренція і підприємництво : монографія. К. : Знання України, 2015. 463 с. 2. Торопков В. М., Сиваненко Г. П. Реформування системи державної підтримки підприємництва в Україні. Проблеми $і$ перспективи розвитку підприємництва. 2017. С. 60-69. 3. Дергачова В. В., Колешня Я. О. Державна підтримка малого і середнього бізнесу в Україні. Науковий вісник Ужгородського національного університету. 2018. № 2. С. 130-133. 4. Новицька О. Інструменти стимулювання малого та середнього бізнесу в контексті регіонального розвитку. Збірник наукових праць чДТУ. Сер. Економічні науки. Вип. 39. Ч. 2. С. 143-149. 5. Державна служба статистики. URL: http://www.ukrstat.gov.ua (дата звернення: 20.06.2021). 6. Про затвердження Програми розвитку малого і середнього підприємництва в місті Рівному на 2020-2021 роки. Рішення Рівненської міської ради від 12.12.2019 р. № 6918. URL: https://economy.rv.ua/pr_msb-program (дата звернення: 20.06.2021). 7. Про державне прогнозування та розроблення програм економічного і соціального розвитку України : Закон України від 23.03.2000 р. №1602-III. Дата оновлення 20.12.2012. URL: https://zakon.rada.gov.ua/laws/show/1602-140 (дата звернення: 20.06.2021).

\section{REFERENCES:}

1. Varnalii Z. S. Konkurentsiia i pidpryiemnytstvo : monohrafiia. K. : Znannia Ukrainy, 2015. 463 s. 2. Toropkov V. M., Syvanenko H. P. Reformuvannia systemy derzhavnoi pidtrymky pidpryiemnytstva $\mathrm{v}$ Ukraini. Problemy $i$ perspektyvy rozvytku pidpryiemnytstva. 2017. S. 60-69. 3. Derhachova V. V., Koleshnia Ya. O. Derzhavna pidtrymka maloho i serednoho biznesu v Ukraini. Naukovyi visnyk Uzhhorodskoho 
natsionalnoho universytetu. 2018. № 2. S. 130-133. 4. Novytska 0. Instrumenty stymuliuvannia maloho ta serednoho biznesu $v$ konteksti rehionalnoho rozvytku. Zbirnyk naukovykh prats ChDTU. Ser. Ekonomichni nauky. Vyp. 39. Ch. 2. S. 143-149. 5. Derzhavna sluzhba statystyky. URL: http://www.ukrstat.gov.ua (data zvernennia: 20.06.2021). 6. Pro zatverdzhennia Prohramy rozvytku maloho i serednoho pidpryiemnytstva v misti Rivnomu na 2020-2021 roky. Rishennia Rivnenskoi miskoi rady vid 12.12.2019 r. № 6918. URL: https://economy.rv.ua/pr_msb-program (data zvernennia: 20.06.2021). 7. Pro derzhavne prohnozuvannia ta rozroblennia prohram ekonomichnoho i sotsialnoho rozvytku Ukrainy : Zakon Ukrainy vid $23.03 .2000 \mathrm{r}$. №1602-III. Data onovlennia 20.12.2012. URL: https://zakon.rada.gov.ua/laws/show/1602-140 (data zvernennia: 20.06.2021).

Savina N. B. [1; ORCID ID: 0000-0001-8339-1219], Doctor of Economics, Professor, Kostiukevych A. M. [1; ORCID ID: 0000-0002-9930-9731], Candidate of Economics (Ph.D.), Associate Professor

${ }^{1}$ National University of Water and Environmental Engineering, Rivne

\section{PROBLEMS OF STIMULATING SMALL AND MEDIUM-SIZED BUSINESS} AT THE REGIONAL LEVEL

One of the problems of the slow development of small and mediumsized businesses in transitive economies is the lack of coherence between the business development programs implemented by local authorities and the real needs of business entities. This result was confirmed on the basis of a survey of small and medium-sized businesses (150 respondents) on the example of one of the local communities of Ukraine. It is proved that the low efficiency of entrepreneurship development programs is due to the methodological flaw that persists in the formation of strategies of community development at different levels. Building the analysis of existing problems and the choice of community development priorities on the methodological principles of environmental analysis, including SWOT analysis, further adjusting strategies using dynamic strategic analysis and balancing of the territorial community project portfolio are not carried out, as a result of which programmatic indicators of goals achievement are usually not achieved.

This is based on the example of an analysis of five topical development strategies that have been developed using a common methodology, each of which supports entrepreneurship as one of the priority operational goals. In order to increase the efficiency of local business development with the support of the authorities, it is proposed to combine the methodology of strategic community development management and the methodological principles of project management.

Another problem is that most business support programs are not synchronized with the expected results of regional and territorial 
development strategies. The main principle «the principle of integrity, which is ensured by the development of mutually agreed forecast and program documents of economic and social development of Ukraine, certain sectors of the economy and certain administrative-territorial units for short and medium term and longer period», which is enshrined in the Law of Ukraine On state forecasting and development of programs of economic and social development of Ukraine.

To implement this principle, regional authorities and local governments are endowed with appropriate powers in the field of small and medium business development, including: 1) determination of regional and local priorities and types of state support taking into account national priorities; 2) development of projects of regional and local programs of small and medium business development, ensuring their implementation taking into account national priorities, national and regional socio-economic, environmental, cultural and other features, monitoring the implementation of such programs. However, today there are no such tools, and therefore at the stage of program development are laid uncoordinated and unattainable planned results and indicators. These problems of application of programtargeted management in the mechanisms of stimulating small business are exacerbated by the lack of connection with development strategies. After all, programs of different levels are just a tool to achieve strategic and operational goals of strategies. In the absence of such a connection, the value of both strategic planning, the results of which become declarative, and the program-targeted management system, which consumes resources aimed primarily at obtaining products of projects and programs, the set of which does not create proper results, without which it is impossible to change the state of the system, for which strategies and programs are developed.

Keywords: small and medium-sized businesses; stimulating the development of entrepreneurship; territorial communities; programs for the development of small and medium-sized businesses.

Савина Н. Б. [1; ORCID ID: 0000-0001-8339-1219], д.э.н., профессор, Костюкевич А. Н. [1; ORCID ID: 0000-0002-9930-9731], к.э.н., доцент

${ }^{1}$ Национальный университет водного хозяйства и природопользования, г. Ровно

ПРОБЛЕМЫ СТИМУЛИРОВАНИЯ РАЗВИТИЯ МАЛОГО И СРЕДНЕГО ПРЕДПРИНИМАТЕЛЬСТВА НА РЕГИОНАЛЬНОМ УРОВНЕ

Одной из проблем медленного развития малого и среднего бизнеса в транзитивных экономиках является недостаточная согласованность программ развития предпринимательства, реализуемых местными 
органами власти, и настоящих потребностей субъектов предпринимательства. Такой результат подтвержден на основе опроса представителей малого и среднего бизнеса на примере одной из локальных общин Украины. Доказано, что низкая эффективность программ развития предпринимательства обусловлена методологической недостаточностью, что сохраняется в формировании стратегий развития общин разного уровня.

Ключевые слова: малое и среднее предпринимательство; стимулирование развития предпринимательства; территориальные общины; программы развития малого и среднего предпринимательства.

Отримано: 20 червня $2021 \mathrm{p}$. Прорецензовано: 24 червня 2021 р. Прийнято до друку: 25 червня 2021 р. 